\title{
Natural regeneration in a beech-dominated forest managed by close-to-nature principles - a gap cutting based experiment
}

\author{
Palle Madsen and Katrine Hahn
}

\begin{abstract}
European beech (Fagus sylvatica L.) is increasingly managed by close-to-nature principles, mimicking the gap dynamics of seminatural forests. The prime aim of this study was to analyse natural regeneration reliability under favourable conditions in newly formed gaps. A total of 12 gaps were created by felling three canopy trees for each gap: six gaps in each of the two winters 1996-1997 and 1997-1998. One-half of the gaps were fenced against deer. We recorded advance regeneration density (1997), regeneration density and height (1997-2002), relative light intensity (1997-2002), and volumetric soil moisture content (1997-2002). We also studied the effect of year of establishment, fenced versus unfenced, and position within gap on regeneration. Three or 4 years after gap formation, most gaps had nearly closed. Response of European beech, European ash (Fraxinus excelsior L. ), and sycamore maple (Acer pseudoplatanus L.) regeneration to gap formation was limited, and few seedlings were added to the advance regeneration pool during the study period. Other factors, such as relative light intensity, soil moisture, fencing, year of establishment, and position within gaps, all had rather low effects. Thus, the presence of advance regeneration appeared to be a key factor in explaining regeneration patterns in artificially created gaps.
\end{abstract}

Résumé : Le hêtre (Fagus sylvatica L.) est de plus en plus aménagé selon des principes proches de la nature visant à imiter la dynamique de trouées des forêts semi-naturelles. Le but premier de cette étude était d'analyser la fiabilité de la régénération naturelle sous des conditions favorables dans des trouées nouvellement formées. Douze trouées ont été créées en abattant trois arbres dominants dans chaque cas. Six de ces trouées ont été créées pendant l'hiver 1996-1997 alors que les six autres ont été créées l'hiver suivant. La moitié des trouées a été clôturée pour empêcher les cerfs d'y pénétrer. Nous avons mesuré la densité de la régénération préétablie en 1997 puis, de 1997 à 2002, la densité et la hauteur de la régénération, la luminosité relative et le contenu volumétrique en eau du sol. Nous avons aussi étudié les effets de l'année d'établissement de la régénération, de la création ou non d'exclos et de la position des semis dans les trouées. Trois à quatre ans après la formation des trouées, la plupart d'entre elles étaient sur le point de se refermer. La régénération de hêtre, de frêne (Fraxinus excelsior L.) et d'érable (Acer pseudoplatanus L.) a peu réagi à la formation des trouées et peu de semis se sont ajoutés à la régénération préétablie pendant la période d'étude. D'autres facteurs comme la luminosité relative, l'humidité du sol, la présence d'exclos, l'année d'établissement de la régénération et la position des semis dans les trouées ont eu peu d'effets. Par conséquent, la présence de régénération préétablie semble être un facteur clé pour expliquer les patrons de régénération dans ces trouées créées artificiellement.

[Traduit par la Rédaction]

\section{Introduction}

Gap regeneration in forests dominated by European beech (Fagus sylvatica L.) has gained in recognition worldwide with the increased interest in close-to-nature forestry. In close-tonature forestry, gaps in a group-selection system are viewed as a method of mimicking natural disturbance regimes (storms, diseases, and pests) to create more natural forest structures than observed in uniform, even-aged plantationlike stands. Studies across regions with beech forests have shown that gaps can $(i)$ increase structural diversity within a forest stand (Angers et al. 2005; Drössler and von Lüpke 2005; Zeibig et al. 2005); (ii) protect forest-dependent biodiversity (Christensen and Emborg 1996; Schnitzler and
Borlea 1998); (iii) provide a suitable forest microclimate for natural regeneration and ground flora (Collins and Pickett 1988; Emborg 1998; Collet et al. 2001; Degen et al. 2005; Ritter et al. 2005a; Hahn and Thomsen 2007); (iv) ensure relatively small changes in biogeochemical processes, where gaps are quickly filled with regeneration or ground flora (Bartsch 2000; Ritter et al. 2005b; Ritter and Vesterdal 2006); and (v) improve stand stability (Emborg and Larsen 1999; Emborg and Heilmann-Clausen 2007). Despite the many advantages of gap regeneration, it appears that predictability of successful regeneration establishment, survival and growth — in both managed forests and unmanaged forest reserves - is low (Galhidy et al. 2006; Hahn et al. 2007); that seedling establishment tends

Received 28 January 2007. Accepted 13 December 2007. Published on the NRC Research Press Web site at cjfr.nrc.ca on 29 May 2008.

P. Madsen. Forest \& Landscape, Faculty of Life Sciences, University of Copenhagen, Vedelsgade 6, DK-7100 Vejle, Denmark.

K. Hahn. ${ }^{1}$ Danish Society for Nature Conservation, Masnedøgade 20, DK-2100 København Ø, Denmark.

${ }^{1}$ Corresponding author (e-mail: khk@dn.dk). 
to be patchy even where conditions appear suitable (Mountford et al. 2006); and that advance regeneration are the only trees to reach the canopy layer before gap closure (McClure et al. 2000; Webster and Lorimer 2005).

In Denmark, traditional natural regeneration methods, which include soil preparation, are known to reliably produce successful regeneration establishment and dense stocking the first spring following a mast year. For forests dominated by beech, the increasing interest in close-to-nature silviculture involves a stronger management focus on mixed-species natural regeneration in gaps, thus avoiding soil preparation in a particular mast year (Hahn et al. 2005). The main practical management concerns about eliminating soil preparation are related to loss of regeneration reliability and increased risk for regeneration failure. Seedling survival could also be reduced by competing ground flora and browsing damage. With regard to browsing, roe deer (Capreolus capreolus L.) are a major threat to newly emerged seedlings (Madsen 1995a). Thus, height growth of European beech, and more so of European ash (Fraxinus excelsior L.) and sycamore maple (Acer pseudoplatanus L.), may be severely reduced by deer browsing (Ammer 1996; Van Hees et al. 1996; Kriebitzsch et al. 2000).

In previous studies of beech regeneration in Denmark, effects of factors including light, soil moisture, nutrient supply (fertilization) and competition were examined to support optimization of the silvicultural method at the stand level (Madsen 1994, 1995b). Results showed strong interactions among these factors, and it was recommended to include this in future research. Madsen and Larsen (1997) studied 22 beech regenerations but found only a small part of the total variation could be explained by the quantified growth factors, and there were no significant interactions identified among growth factors. However, we suggested that future studies of growth factor effects should include the year of establishment. Therefore, in 1997-1998, we established a series of gap-regeneration experiments to study (i) the reliability of natural regeneration, (ii) the effects of deer browse, and (iii) the gap effects of light and soil moisture. These experiments were conducted at several sites in Denmark representing various forest conditions and management regimes. In this paper, we describe the results from a gapcutting experiment in the forest Als Nørreskov, which has been managed by close-to-nature principles since 1960 (Madsen and Fodgaard 1989; Madsen et al. 1999).

Our hypotheses are as follows: (H1) regeneration density and height are positively related to increased light and soil moisture, and there is a positive interaction between light and soil moisture on regeneration density and height, (H2) the central and northern parts of the gaps will foster the densest and tallest regeneration within the first 5 years due to more favourable light and soil moisture conditions, (H3) the presence of advance regeneration plays a crucial role in determining success of regeneration in gaps, (H4) in deerfenced gaps, natural regeneration of beech, ash, and sycamore maple will establish reliably and in significantly higher densities (in total e.g., $>5 \mathrm{~m}^{-2}$ within 5 years after gap formation) than in unfenced gaps, and (H5) deer-fences will significantly increase regeneration height growth - particularly for ash and sycamore maple.
Fig. 1. Als Nørreskov is a $9 \mathrm{~km}$ long forest situated on the east coast of the island Als in southwestern Denmark. The approximate position of gaps 1-12 are indicated on the enlarged map of the forest. Broken lines are forest roads.

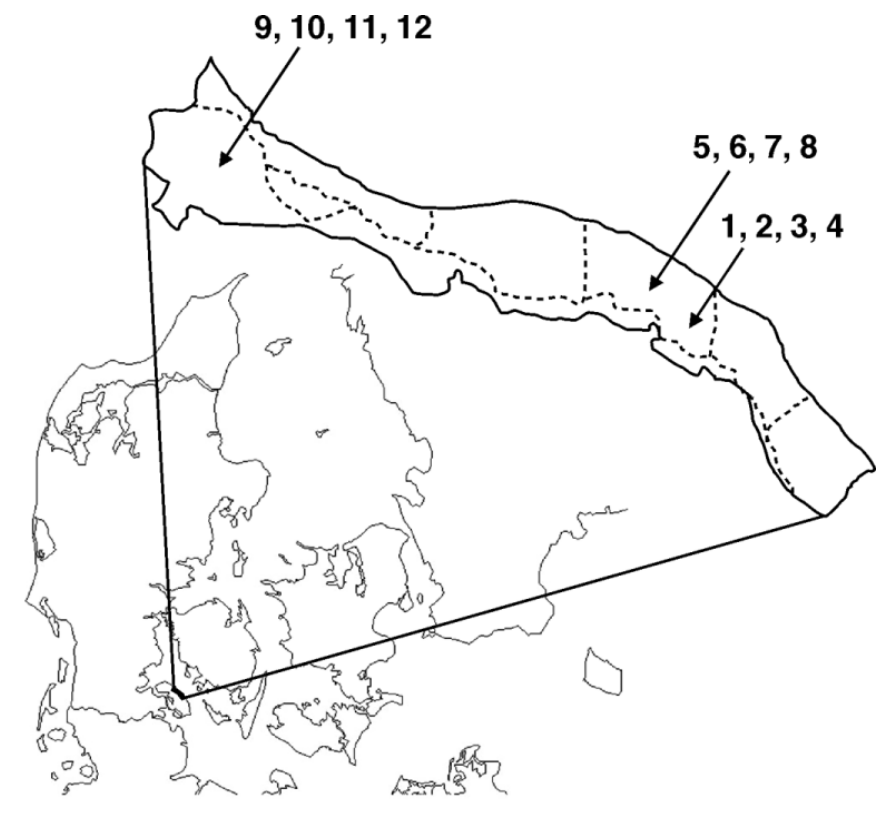

\section{Materials and methods}

\section{Site description}

The study site, Als Nørreskov $\left(55^{\circ} 01^{\prime} \mathrm{N}, 9^{\circ} 55^{\prime} \mathrm{E}, 0-29 \mathrm{~m}\right.$ above sea level, $750 \mathrm{ha}$ ), is an old deciduous forest on the eastern shore of the island Als in southern Denmark (Fig. 1).We established the gaps in stands with trees of up to 110 years old (Fig. 1). The area has presumably always been a forested landscape and was officially registered as forest in the 18th century (Royal Danish Academy of Science and Letters 1783). The forest is presently dominated by beech, with some ash and sycamore maple and has an uneven-aged structure with a well-developed understorey. Mean canopy height is $33 \mathrm{~m}$, and mean overstorey diameter at breast height was $53 \mathrm{~cm}$. Mean annual temperature is $8.2{ }^{\circ} \mathrm{C}$ (Laursen et al. 1999), and mean annual precipitation is $674 \mathrm{~mm}$ (Frich et al. 1997). The soil has been classified as a Hapludalf, and the parent material is glacial deposits (Ritter and Vesterdal 2006). Mean deer density is estimated at 15 roe deer $100 \mathrm{ha}^{-1}$ (Andersen 2000). The history of close-to-nature silviculture in Als Nørreskov dates back to the 1960s, when the aim was to maintain a high percentage of broadleaves, mainly beech, by natural regeneration. This was then quite different from the general trend in Danish forestry to replace broadleaves with conifers, mainly Norway spruce (Picea abies (L.) Karst.). From 1970, silviculture practiced in Als Nørreskov has become increasingly close-to-nature oriented by applying a method of natural regeneration within an irregular shelterwood system produced by target diameter cutting.

A total of 12 gaps were created for the study by cutting three large, neighbouring beech trees for each gap. Six gaps were established in winter 1996-1997 (13 March 1997) and six gaps in winter 1997-1998 (10 February 1998). Mean gap size was $300 \mathrm{~m}^{2}\left(180-470 \mathrm{~m}^{2}\right)$. Gaps were cut in two differ- 
Fig. 2. Schematic representation of the 12 gaps, the enclosure "treatment," and the year of gap establishment (winter 1996-1997 and winter 1997-1998) (left panel). The fenced plots are shown in boxes. Large open circles indicate the gaps (canopy opening). The right panel shows the sampling design within and around one gap with the 91 circular sampling plots and the grouping into 11 positions. The small solid circle is the sample plot considered to be in the centre of the gap. In the top right corner, a diagram show the relative sizes of the sample units of 1997-1999 (circle, $0.3 \mathrm{~m}^{2}$ ) versus 2000-2002 (semicircle, $1.5 \mathrm{~m}^{2}$ ).
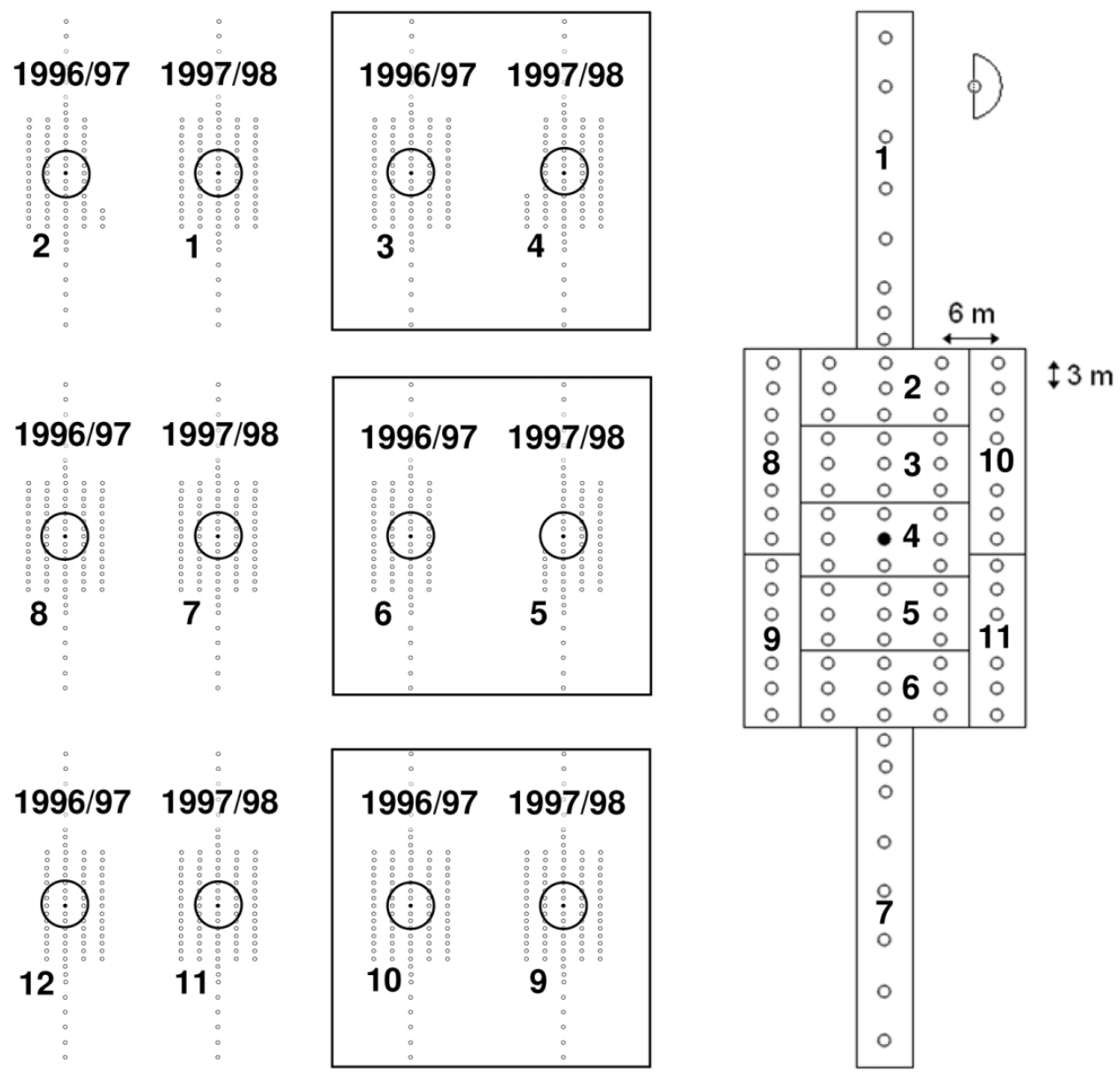

ent years to test the effect of year and if there was a difference between gap establishment in a nonmast year (1997) or a mast year (1998). Gap placement was based on several criteria: closed canopy cover, relatively flat terrain, uniform soil conditions, and absence of dominant advance regeneration. Understorey trees were not felled because we (i) intended to mimic the natural gap formation as closely as possible and (ii) wanted to study interactions between light and soil moisture. For the latter purpose, we expected plots located at sites with good water supply but low light to be very useful because we then would have all four combinations of low or high light and soil moisture represented at various places in and around gaps. Fences (1.4 m height) were installed around one-half of the studied gaps (gaps 3, 4, 5, 6, 9, and 10) in pairs (total of three fences) (29 May 1997) to examine the effect of roe deer exclusion on forest regeneration (Fig. 2). Selection of which gaps to be fenced was based on physical and logistical constraints, e.g., we avoided areas with forest roads. No preference for establishment of fences was made to site conditions or the presence of advance regeneration. Each fence included one gap from each of the two years.

\section{Sampling and analyses}

For each of the 12 gaps, sampling was done in 91 plots organized in a $3 \mathrm{~m} \times 6 \mathrm{~m}$ grid system. The grid had a central north-south baseline $(120 \mathrm{~m})$ and four parallel sidelines (42 m each; two east and two west of the baseline) that covered the gap centre as well as surrounding closed forest (Fig. 2). Of the total 1092 sample plots, 87 plots from the outermost edges of the grid were excluded because they were too close to neighbouring gaps. Gap boundaries, defined as vertical crown projections of surrounding canopy trees on the forest floor (sensu Runkle 1982), were mapped in summer 1998, and gap area was calculated from the polygons. Understorey beech trees present inside the gaps were not excluded from the calculated gap area.

Leaf area index (LAI) of the canopy was determined with a LI-COR LAI-2000 plant canopy analyzer (Welles and Norman 1991) in 1997, 1998, 1999, 2001, and 2002. Simultaneous measurements of the gap fraction on five concentric rings were taken with two cross-calibrated sensors under uniformly overcast conditions. The "above-canopy" sensor was placed on open land adjacent to the forest, and the "below-canopy" sensor was used for measurements $1 \mathrm{~m}$ above 
all plots. A $90^{\circ}$ cover cap was mounted on both sensors to exclude the northern quadrant canopy of the sensor by orientating the sensors southwards. Hereby, canopy density of the three quadrants (east, south, and west), which influence both direct and diffuse forest floor light, was given priority in the quantification of the light conditions in each plot; see also Madsen and Larsen (1997). LAI data were converted to relative light intensity, photosynthetic photon flux densities (PPFD, $\mu \mathrm{mol} \cdot \mathrm{m}^{-2} \cdot \mathrm{s}^{-1}$ ) in the 400 $700 \mathrm{~nm}$ waveband. The conversion was based on regression analyses of LAI and PPFD measurements in a comparable beech forest in eastern Denmark (Madsen and Larsen 1997).

Volumetric soil moisture content was measured at all plots along the baseline during a dry spell in the vegetation periods of 1997, 1998, 1999, 2001, and 2002. Measurements from 2001 and 2002 were not included in the statistical analyses because the measurements showed a very high soil moisture content; the measurement was so high that we assume there were technical problems with the measurements both years. Measurements were carried out with a cable tester (Tektronix 1502C) for two sets of probes at each plot at $0-30 \mathrm{~cm}$ depth using time domain reflectometry (TDR). Data were converted to volumetric soil moisture content by the calibration of Topp et al. (1980) embedded in the software AUTOTDR by Thomsen (1994) and converted to percentages of field capacity (compared with winter field capacity measured late winter 1997).

Regeneration was recorded for all plots within and around all 12 gaps. We used circular plots of $0.3 \mathrm{~m}^{2}(r=0.3 \mathrm{~m})$ in 1997-2000 and semicircular plots of $3.5 \mathrm{~m}^{2}(r=1.5 \mathrm{~m})$ in 2001-2002 (Fig. 2). Recordings of regeneration, species, density, and height of tallest seedling by species (maximum height, $\mathrm{cm}$ ), were carried out by the end of each growing season (October-November) in the sampling period. Regeneration was defined as all young trees (seedlings and saplings) $<6 \mathrm{~m}$ tall in the $0.3 \mathrm{~m}^{2}$ plots, whereas only regeneration taller than $0.5 \mathrm{~m}$ was recorded in the $3.5 \mathrm{~m}^{2}$ plots. The shift in plot size was done to accommodate future experimental recordings of the regeneration and because a large proportion of the smaller plots had no seedlings. Advance regeneration density was only recorded during July 1997 and defined as seedlings (by species) from before spring 1997. Advance regeneration height was not measured. We did not have resources available for a precise differentiation between advance regeneration and new regeneration in the following recordings. We also had to only record the taller $(>0.5 \mathrm{~m})$ seedlings in those larger plots. Regeneration density was calculated for each plot and species as young trees per square metre.

The 91 sample plots of each gap were pooled into 11 larger plots, corresponding to the 11 positions defined within and around a gap (Fig. 2, right panel). Means of regeneration density, maximum height, light, and soil moisture were calculated for each position. Regeneration density and regeneration height were log transformed. Mixed models with repeated measurements (MIXED procedure) (SAS, version 8.2; SAS Institute Inc., Cary, N.C.) were used to test the effects of light and soil moisture (both measured in 1998, which was the first year after all gaps were established), density of advance regeneration (covariate), fencing ("fenced" or "unfenced," class variable), year of gap establishment
(1997 or 1998, class variable), and position within gap (position 1-11, class variable) on mean regeneration density and maximum regeneration height. Year of gap establishment was nested within fencing. Year was the repeated measure. The 12 gaps were included in the statistical models as a random effect. We analysed different alternative measurement dates and years to represent the light and soil moisture factors but found that the 1998 measurements generally gave the best overall representation of the two factors for our statistical models. The models were run for each of the three main species (beech, ash, and sycamore maple) in two periods (1997-2000, measurements in small plots; 2001-2002, measurements in large plots). Because soil moisture was measured only along the centre lines in the fenced gaps, there were two statistical models tested (a) including soil moisture but excluding fencing and (b) excluding soil moisture but including fencing. The models reported did not include interactions between variables. However, we did also test the interactions soil moisture $\times$ light and light $\times$ position. For all models, effects were considered significant when $p \leq 0.05$.

The models for advance regeneration density were as follows: $\ln ($ advance regeneration density +1$)=$ position, fencing, year of establishment (nested within fencing), and light for the full data set (model $0 a$ ) and $\ln ($ advance regeneration density +1$)$ = position, year of establishment, light, and soil moisture for the reduced data set (model $0 b$ ). The models for regeneration density were as follows: $\ln$ (regeneration density +1$)$ = year, position, fencing, year of establishment (nested within fencing), light, and advance regeneration for the full data set (model 1a) and $\ln$ (regeneration density +1$)$ = year, position, year of establishment, light, soil moisture, and advance regeneration for the reduced data set (model $1 b$ ). The models for regeneration height were as follows: $\ln ($ regeneration height +1$)=$ year, position, fencing, year of establishment (nested within fencing), and light for the full data set (model $2 a$ ) and $\ln$ (regeneration height +1$)=$ year, position, year of establishment, light, and soil moisture for the reduced data set (model $2 b$ ).

\section{Results}

\section{Light and soil moisture conditions}

Analyses of the spatial patterns of relative light intensity (RLI) show that RLI increased from a mean of $2 \%-3 \%$ under closed canopy to $6 \%-8 \%$ in the gaps, with highest values slightly north of the gap centre (Fig. 3). However, in some gaps, the effect of gap cutting was almost negligible, and by 2001 (3 or 4 years after gap formation), most gaps had closed considerably because of lateral expansion of branches and crowns from neighbouring trees and understorey trees.

Soil moisture conditions varied with seasons, years, and position in gaps. In general, soil moisture availability was higher in the gap centre than under closed canopy cover during dry periods of the growing season. In moist periods, typically early spring, soil moisture stayed close to $100 \%$ of field capacity in all sample plots. Depending on the pattern and quantity of summer precipitation and evapotranspiration, a gap effect on soil moisture availability was detected as early as June (1998; Fig. 4b) but, typically, not until August 
Fig. 3. (a) Gap effects on relative light intensity (RLI) are shown for 1997, 1998, 1999, 2001, and 2002 along transects through the gaps created before the 1997 growing season. Values are means for six gaps (2, 3, 6, 8, 10, and 12) established in winter 1996-1997. Standard errors of the means (SEs) for each year are as follows: 1997, $\mathrm{SE}=1.32 ; 1998, \mathrm{SE}=1.23 ; 1999, \mathrm{SE}=1.10 ; 2001, \mathrm{SE}=1.06 ; 2002, \mathrm{SE}=$ 0.94. (b) Gap effects on RLI are shown for 1998, 1999, 2001 and 2002 along transects through the gaps created before the 1998 growing season. Values are means for six gaps $(1,4,5,7,9$, and 11) established in winter 1997-1998. SEs for each year are as follows: 1998, SE = $1.19 ; 1999, \mathrm{SE}=1.10 ; 2001, \mathrm{SE}=1.06 ; 2002, \mathrm{SE}=1.24$.
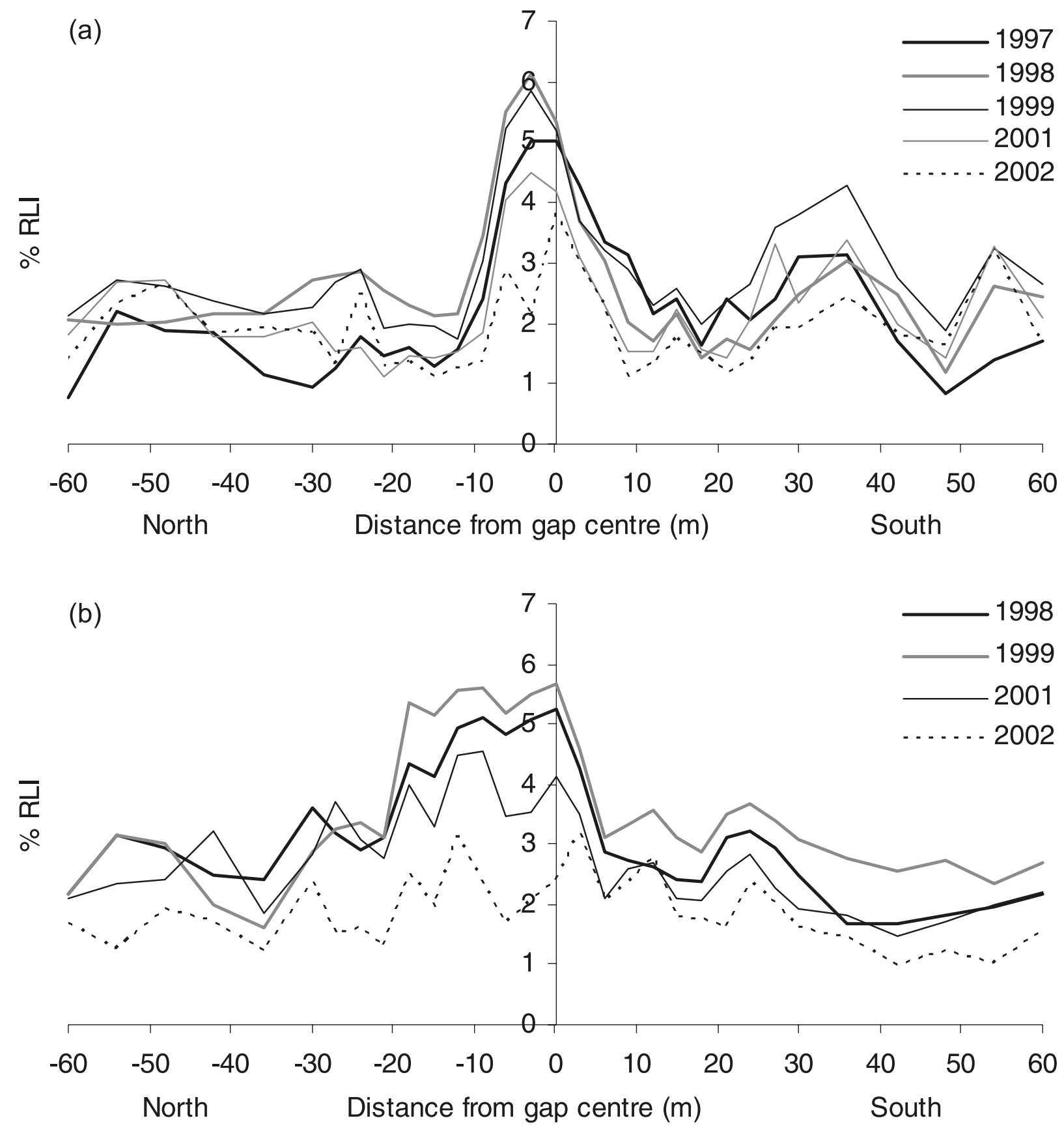

(Figs. $4 a$ and 5) when soil moisture dropped down to $40 \%-$ $50 \%$ of field capacity under closed canopy.

The considerable change in patterns of soil moisture availability from a closed-canopy situation to a newly cut gap situation is illustrated in Fig. $5 b$, where measurements from 1997 (before gap cutting) contrast measurements from 1998 (after gap cutting). The subsequent and gradual closing of the gaps was partly detectable; we observed a narrower area with high soil moisture content in dry spells in 1999 than 1998 (Fig. 5).

\section{Advance regeneration}

Advance regeneration occurred in all gaps at the time of gap formation and consisted mainly of beech and ash. Within gaps, there was a tendency of advance regeneration to be present in higher numbers in positions outside the 
Fig. 4. (a) Change in mean soil moisture through the first growing season after gap formation (1997). Values are means for gaps 3 , 6, and 10, which were cut 13 March 1997. After a gradual decrease in soil moisture availability, a marked drop occurred in August 1997, with much lower soil moisture availability under closed canopy. Only in the gap centre did soil moisture availability remain high. Standard errors of the means (SEs) for each month are as follows: April, $\mathrm{SE}=3.2$; May, $\mathrm{SE}=3.6$; June, $\mathrm{SE}=4.1$; July, $\mathrm{SE}=6.5$; August, $\mathrm{SE}=10.2$. (b) Change in mean soil moisture (\% of field capacity) through the first growing season after gap formation (1998). Values are means for gaps 4, 5, and 9, which were cut 10 February 1998. Soil moisture availability remained high in the gap centre throughout the growing season. Under closed canopy, soil moisture availability dropped in June, increased again after precipitation in July, and dropped considerably again in August-October. Generally, precipitation during the growing season 1998 was considerable higher than in 1997. SEs for each month are as follows: May, = 7.1; June, $\mathrm{SE}=7.5$; July, $\mathrm{SE}=10.4$; August, $\mathrm{SE}=12.8$; October, $\mathrm{SE}=14.3$.
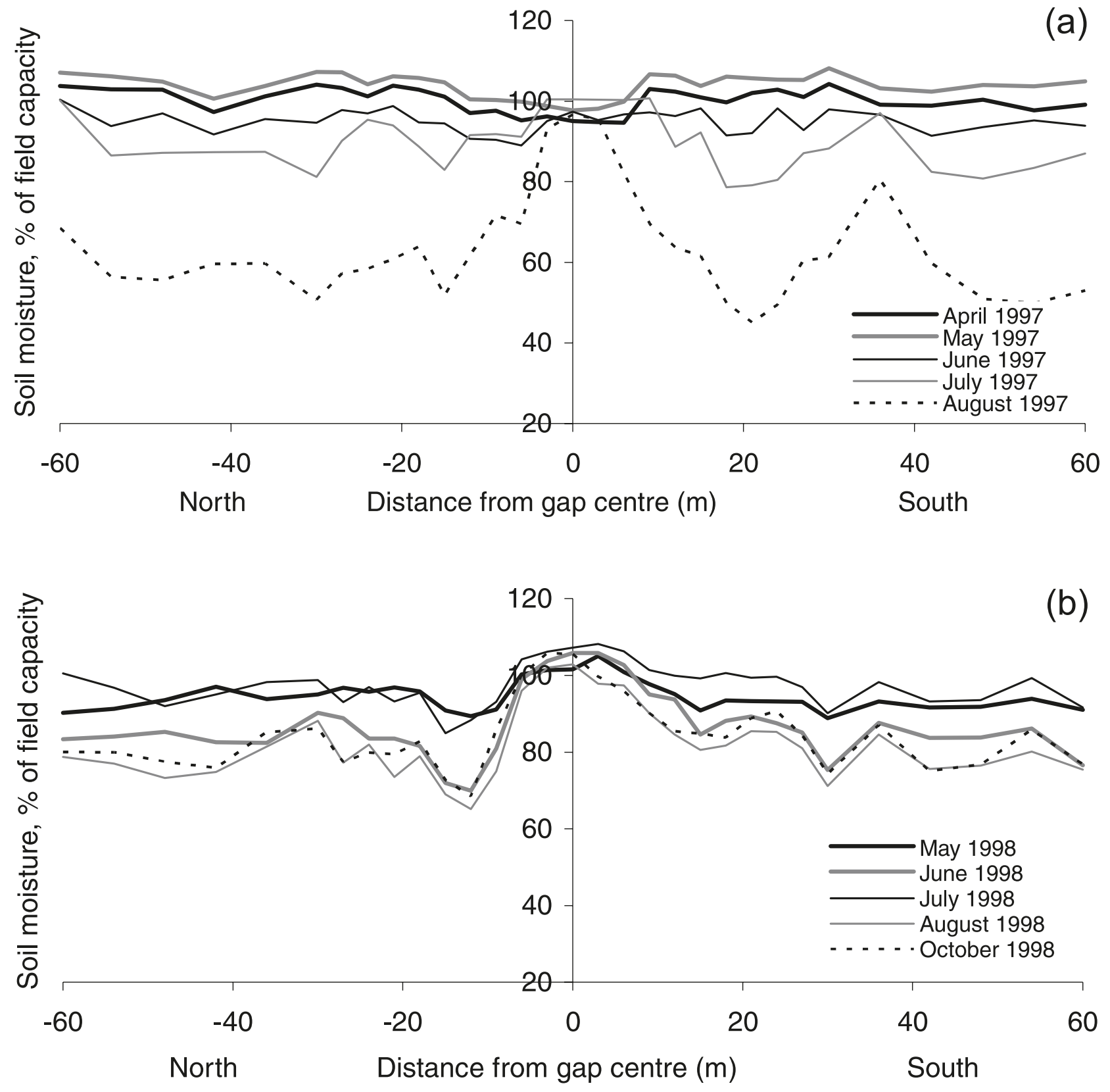

gap centres $\left(1-4.5\right.$ plants $\left.\cdot \mathrm{m}^{-2}\right)$ than in the gap centres $(0-$ 1.5 plants $\cdot \mathrm{m}^{-2}$ ). However, statistical analyses (models $0 a$ and $0 b$ ) showed no significant effects. The gaps were placed at sites that, from the beginning, seemed to have less regeneration than in the rest of the forest. However, this was not expressed in significant effects of position, when the gaps were created.

\section{Regeneration density}

Regeneration densities were rather low at the beginning of the experiment; mean plant densities were 0-1 sycamore maple $\cdot \mathrm{m}^{-2}, 1-3 \mathrm{ash} \cdot \mathrm{m}^{-2}$, and $0-5$ beech $\cdot \mathrm{m}^{-2}$ (Fig. 6). Beech and ash densities clearly increased in 1999 and subsequently declined in 2000 (Fig. 6), which were patterns underlined by the highly significant year effects $(P<0.0001)$ for models 
Fig. 5. (a) Gap effects on mean soil moisture are shown for the dry periods of the 1997, 1998, and 1999 growing seasons along transects through the gaps created before the 1997 growing season. Measurements were carried out 14 August 1997, 18 August 1998, and 18 September 1999. Values are means for the three gaps (3, 6, and 10) established in winter 1996-1997. Standard errors of the means (SEs) for each year are as follows: August 1997, SE $=10.2$; August 1998, SE $=12.8$; September 1999, SE $=13.5$. (b) Gap effects on mean soil moisture (\% of field capacity) are shown for the dry periods of the 1997, 1998, and 1999 growing seasons along transects through the gaps created before the 1998 growing season. Note the dramatic change in soil moisture from 1997 to 1998 created by the gap cutting in the 1997-1998 winter. Measurements were carried out 14 August 1997, 18 August 1998, and 18 September 1999. Values are means for the three gaps (4, 5, and 9) established in winter 1997-1998. SEs for each year are as follows: August 1997, SE = 13.9; August 1998, SE = 12.8; September 1999, $\mathrm{SE}=19.2$.
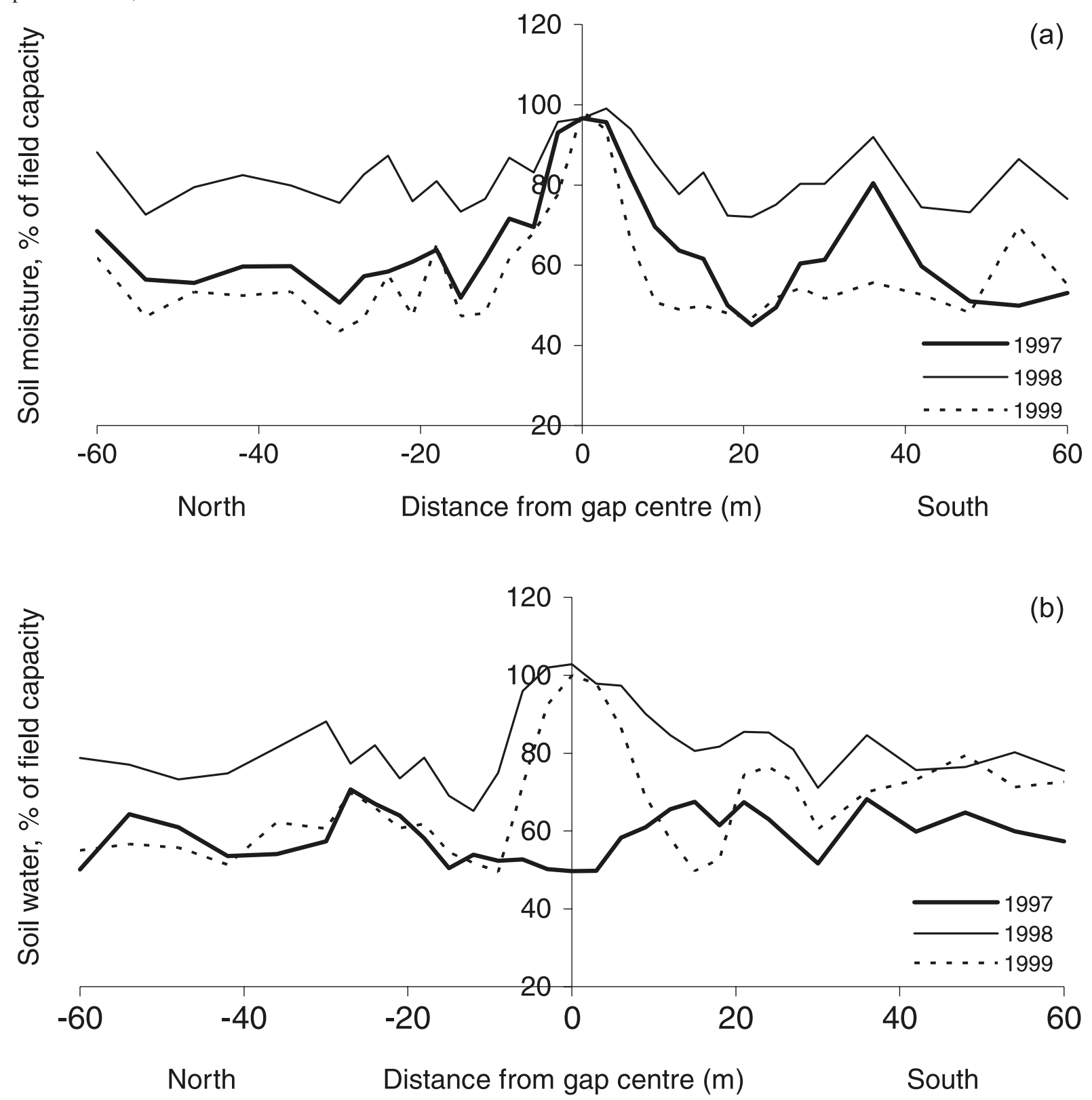

$1 a$ and $1 b$ in the period 1997-2000 (Table 1). For sycamore maple, regeneration density was consistently low in the whole period. Advance regeneration density had a consistent and highly significant effect for both models $1 a$ and $1 b$ and, as such, was the main factor controlling the regeneration density. Except for ash regeneration density in the last period (2001-2002), the $P$ values of advance regeneration were $<0.0001$.
The effect of position was significant to highly significant for beech (model 1b), ash (model 1a), and sycamore maple (both models). All three species had lowest densities in gap centres (position 4; see Fig. 2, right panel). Fence and year of establishment showed no significant effects.

In model $1 b$ (Table 1 ), light and soil moisture had significant negative and positive effects, respectively, for beech in 1997-2000. For ash and sycamore maple, the pattern was 
Fig. 6. Mean density of regeneration in sample plots for 1997-2000: left column, plots in gaps established in 1997; right column, plots in gaps established in 1998. Open symbols indicate sample plots outside fenced gaps; solid symbols indicate sample plots inside fenced gaps. $\mathrm{j}$. 1997, July 1997; n. 1997, November 1997.
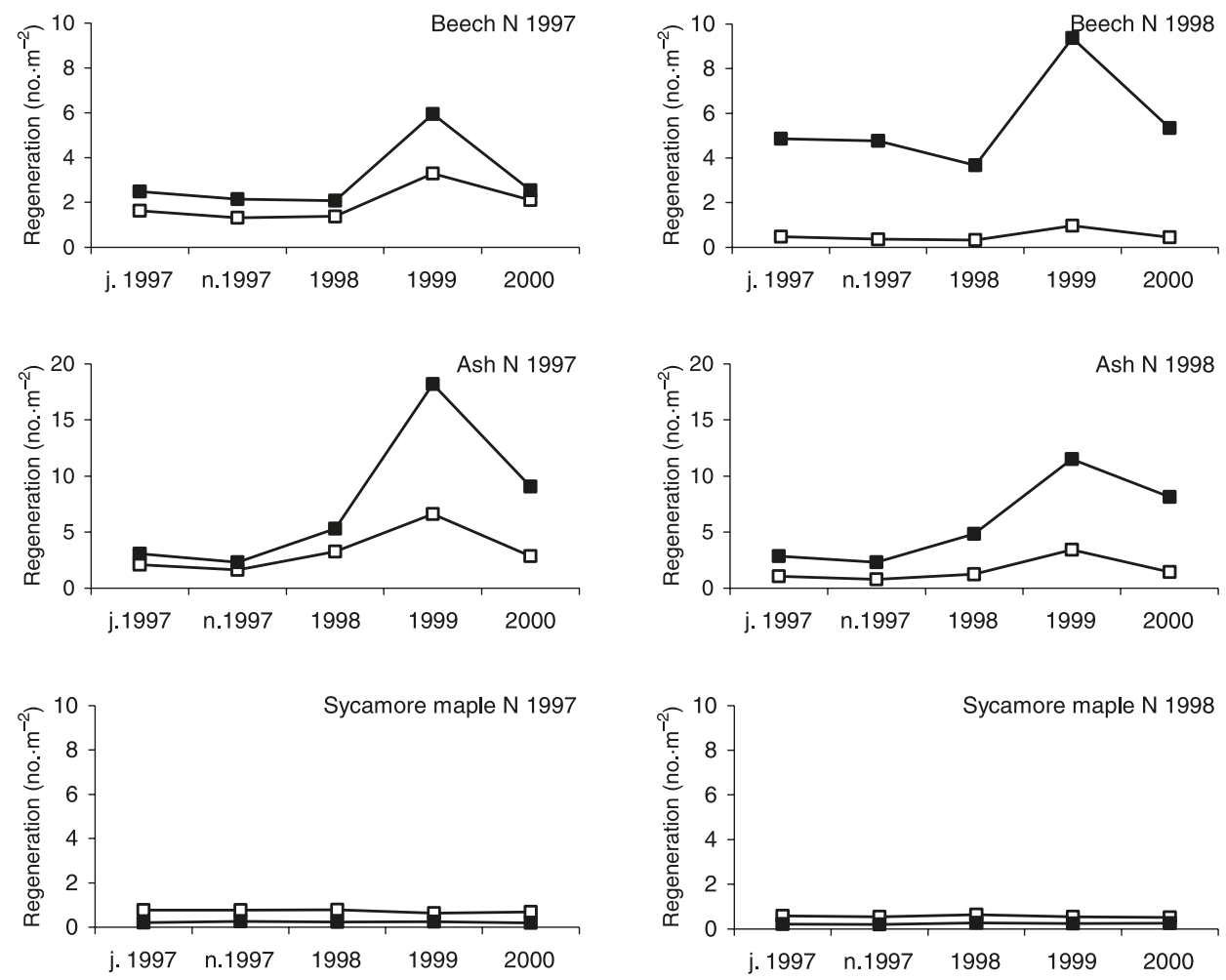

Table 1. Statistical results ( $P$ values) for regeneration density (models $1 a$ and $1 b$ ) in the two different observation periods (1997-2000 in small plots and 2001-2002 in large plots excluding regeneration $<50 \mathrm{~cm}$ tall).

\begin{tabular}{|c|c|c|c|c|c|c|c|}
\hline $\begin{array}{l}\text { Species, model, } \\
\text { and period }\end{array}$ & Year & Position & Fence & $\begin{array}{l}\text { Year of } \\
\text { establishment }\end{array}$ & Light & $\begin{array}{l}\text { Soil } \\
\text { moisture }\end{array}$ & $\begin{array}{l}\text { Advance } \\
\text { regeneration }\end{array}$ \\
\hline \multicolumn{8}{|c|}{ European beech, including fence effect (model $1 a)$} \\
\hline $1997-2000$ & $<0.0001$ & 0.4282 & 0.1972 & 0.7433 & 0.5730 & & $<0.0001$ \\
\hline $2001-2002$ & 0.7417 & 0.3596 & 0.2757 & 0.9136 & 0.2678 & & $<0.0001$ \\
\hline \multicolumn{8}{|c|}{ European beech, including soil moisture effect (model $\mathbf{1 b}$ ) } \\
\hline $1997-2000$ & $<0.0001$ & 0.0157 & & 0.5974 & 0.0020 & 0.0038 & $<0.0001$ \\
\hline 2001-2002 & 0.6890 & 0.0657 & & 0.8536 & 0.0925 & 0.0640 & $<0.0001$ \\
\hline \multicolumn{8}{|c|}{ European ash, including fence effect (model $1 a)$} \\
\hline $1997-2000$ & $<0.000$ & 0.0115 & 0.5014 & 0.9352 & 0.7304 & & $<0.0001$ \\
\hline 2001-2002 & 0.6045 & 0.0049 & 0.1581 & 0.3144 & $<0.0001$ & & $<0.0001$ \\
\hline \multicolumn{8}{|c|}{ European ash, including soil moisture effect (model $1 b$ ) } \\
\hline 1997-2000 & $<0.0001$ & 0.3885 & & 0.7489 & 0.0003 & 0.8205 & $<0.0001$ \\
\hline 2001-2002 & 0.6332 & 0.9370 & & 0.0667 & 0.9355 & 0.3499 & 0.2720 \\
\hline \multicolumn{8}{|c|}{ Sycamore maple, including fence effect (model $1 a$ ) } \\
\hline $1997-2000$ & 0.8901 & $<0.0001$ & 0.7138 & 0.3153 & 0.7809 & & $<0.0001$ \\
\hline $2001-2002$ & 0.9760 & 0.0394 & 0.8619 & 0.9891 & 0.1354 & & $<0.0001$ \\
\hline \multicolumn{8}{|c|}{ Sycamore maple, including soil moisture effect (model $\mathbf{1 b}$ ) } \\
\hline $1997-2000$ & 0.3487 & 0.0475 & & 0.6682 & 0.6615 & 0.4738 & $<0.0001$ \\
\hline $2001-2002$ & 0.4252 & 0.0053 & & 0.8224 & 0.0091 & 0.0840 & $<0.0001$ \\
\hline
\end{tabular}

Note: The results including soil moisture effects exclude fence effects because soil moisture only was measured in fenced gaps. 
Fig. 7. Maximum height of regeneration in sample plots for 1997-2000: left column, plots in gaps established in 1997; right column, plots in gaps established in 1998. Open symbols indicate sample plots outside fenced gaps; solid symbols indicate sample plots inside fenced gaps. n. 1997, November 1997.
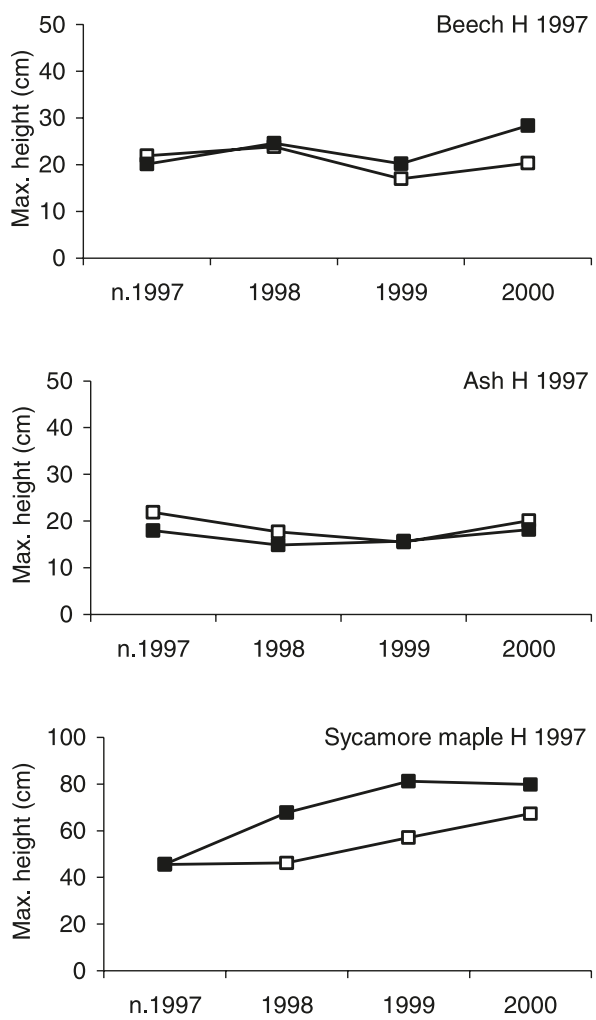

less clear, with significant positive effects of light only in 1997-2000 (model 1b) and in 2001-2002 (model $1 a$ for ash and model $1 b$ for sycamore maple).

\section{Regeneration height}

At the beginning of the experiment (1997), the maximum height of regeneration was $20-30 \mathrm{~cm}$ for beech, $20 \mathrm{~cm}$ for ash, and 20-45 cm for sycamore maple (Fig. 7). Height development was not clear. Maximum height of beech and ash went significantly up and down over the years 19972000 and, by the end of this period maximum height, showed only a small increase. Statistical analyses of which variables had a significant effect on height of regeneration also provided inconsistent results. Fencing was only significant for beech (1997-2000; model 2a). The position effect was significant for all three species through the whole study period except for beech 2001-2002 (model 2b) and sycamore maple 1997-2000 (model 2b). For beech and ash, the shortest seedlings were located in the gap centres, whereas there was no clear pattern for sycamore maple. Year of establishment had a sporadic but significant effect on height of beech in 2001-2002 (model 2a). Light was generally significant for sycamore maple except for model $2 b$ in 1997-2000 and for ash in 1997-2000 (model 2a), with taller plants at higher RLI. On the contrary, beech was negatively influenced by increased light: model $2 b$ showed a significantly negative impact. Soil moisture availability had a significant positive effect on beech and sycamore maple height in 1997-2000 and 2001-2002 (model 2b), respectively (Table 2).
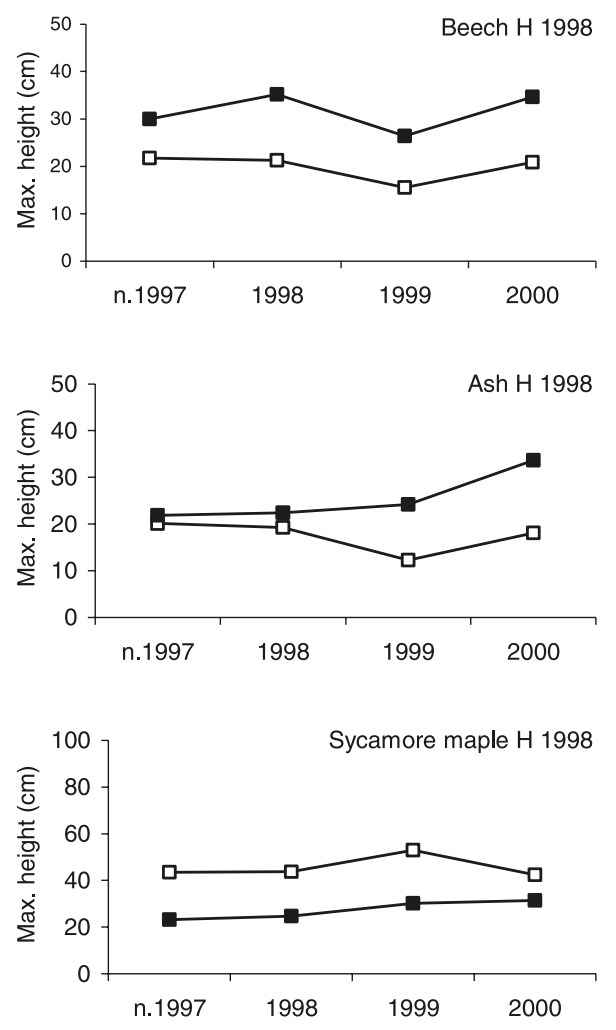

\section{Discussion}

The purpose of the study was to examine how natural regeneration would establish in recently cut gaps (without soil preparation) not already occupied by extensive, advance regeneration. Based on previous studies and the literature, we expected significant and positive effects of light and soil moisture availability as well as a positive interaction between the two on regeneration establishment (density and growth). We also expected better regeneration establishment where deer were excluded (fencing) and in the artificially established gaps, particularly in the northern part of gaps. Many results were not what we expected. Despite a sharp increase in ash and beech regeneration in 1999, the decrease in the subsequent years meant that little new regeneration was added to the regeneration pool by the end of the study period. Moreover, we did not find the expected clear effect from growth factors, the fence, the gaps, or the position within the gaps.

\section{The effect of light, soil moisture, advance regeneration, and ground vegetation}

Light and soil moisture increased markedly following gap formation, reaching the highest values in the gap centre (light and soil moisture) and just north of the gap (light). This corresponds well with observations from many other studies that an opening in the canopy provides a marked improvement in light and soil water availability (e.g., Ritter et al. 2005a; Galhidy et al. 2006; Ritter and Vesterdal 2006; Dalsgaard 2007). Gap effects on light and soil moisture 
Table 2. Statistical results ( $P$ values) for regeneration height (models $2 a$ and $2 b$ ) in the two different observation periods (1997-2000 in small plots, 2001-2002 in large plots excluding regeneration $<50 \mathrm{~cm}$ tall).

\begin{tabular}{|c|c|c|c|c|c|c|}
\hline $\begin{array}{l}\text { Species, model, } \\
\text { and period }\end{array}$ & Year & Position & Fence & $\begin{array}{l}\text { Year of } \\
\text { establishment }\end{array}$ & Light & $\begin{array}{l}\text { Soil } \\
\text { moisture }\end{array}$ \\
\hline \multicolumn{7}{|c|}{ European beech, including fence effect (model $2 a$ ) } \\
\hline $1997-2000$ & $<0.0001$ & $<0.0001$ & 0.0120 & 0.3169 & 0.1834 & \\
\hline 2001-2002 & 0.8121 & 0.0018 & 0.4433 & 0.0105 & 0.2074 & \\
\hline \multicolumn{7}{|c|}{ European beech, including soil moisture effect (model $2 b$ ) } \\
\hline $1997-2000$ & 0.0207 & $<0.0001$ & & 0.0762 & 0.2585 & 0.0005 \\
\hline 2001-2002 & 0.8375 & 0.2019 & & 0.2102 & 0.0319 & 0.3088 \\
\hline \multicolumn{7}{|c|}{ European ash, including fence effect (model $2 a$ ) } \\
\hline $1997-2000$ & 0.0062 & $<0.0001$ & 0.2724 & 0.5350 & 0.0001 & \\
\hline 2001-2002 & 0.9303 & 0.0056 & 0.6349 & 0.4463 & 0.4950 & \\
\hline \multicolumn{7}{|c|}{ European ash, including soil moisture effect (model $2 b$ ) } \\
\hline $1997-2000$ & 0.0005 & $<0.0001$ & & 0.0930 & 0.0782 & 0.5353 \\
\hline 2001-2002 & 0.4683 & 0.0139 & & 0.6589 & 0.9998 & 0.6877 \\
\hline \multicolumn{7}{|c|}{ Sycamore maple, including fence effect (model $2 a$ ) } \\
\hline $1997-2000$ & 0.2656 & $<0.0001$ & 0.2803 & 0.1574 & 0.0117 & \\
\hline 2001-2002 & 0.6141 & $<0.0001$ & 0.1424 & 0.9409 & 0.0001 & \\
\hline \multicolumn{7}{|c|}{ Sycamore maple, including soil moisture effect (model $2 b$ ) } \\
\hline $1997-2000$ & 0.8954 & 0.0877 & & 0.7072 & 0.6827 & 0.3829 \\
\hline 2001-2002 & 0.7402 & $<0.0001$ & & 0.9265 & 0.0021 & 0.0083 \\
\hline
\end{tabular}

lasted throughout the experimental period, but light availability levelled off within 3 or 4 years after gap formation. Similar short-lived increases in resource availability ( $<3$ years) have been reported by Aussenac (2000), Muth and Bazzaz (2002), and Dalsgaard (2007). The gap effect of light was rather small and was soon reduced further by lateral growth of branches of neighbouring canopy trees and understorey trees (Fig. 3). This is probably one of the main factors in explaining why new regeneration failed shortly after establishment. The longer lasting gap effect in soil moisture was probably due to a slower process of fine-root ingrowth of trees surrounding the gaps (Bauhus and Bartsch 1996). Density-dependent plant mortality is sometimes considered a factor to explain the observed mortality. In this study, only 6 (beech) and 15 (ash) plots (of 1092 plots) had densities exceeding 70 seedlings $\cdot \mathrm{m}^{-2}$. Sycamore maple never exceeded a density of 13 seedlings $\cdot \mathrm{m}^{-2}$. We did not observe density-dependent mortality in any of the plots with high densities. Figure 6 clearly demonstrates that those peak densities were both rare and extreme, compared with mean plant densities. Additionally, densities in those plots peaked when the majority of seedlings were 1 year old and $<10 \mathrm{~cm}$ tall. Therefore, we conclude that density-dependent mortality did not cause early mortality following seedling recruitment.

In comparable studies of gap regeneration in beech forests, seedling density is highest at the gap fringe or just outside the gap (Mountford et al. 2006), whereas the tallest plants are recorded in the gap centre (Ritter et al. 2005a), corresponding to the increased resource availability there. In our study, the increase in resource availability was not matched by a strong response of regeneration. Beech regeneration density increased with soil moisture but decreased with light. The negative light effect was particularly surpris- ing because there is no physiological explanation for the correlation. Why did light negatively influence beech regeneration? The negative effect was probably because we intentionally selected gap centres where there was less regeneration and ground flora than in the surrounding forest. This did not create significant position effects on the advance regeneration; however, all three species showed significant position effects, and they had the lowest densities in the gap centres. The fact that heavy beech mast in autumn 1998 (Fig. 6) only caused a temporary increase in the density patterns set by the advance regeneration is probably linked to the marked decrease in resource availability in the fast-closing gaps (Figs. 3 and 6). The $P$ value of advance regeneration remains highly significant $(P<0.0001)$ for all three species throughout the study period except for ash in 2001-2002, whereas the significance of soil moisture and light is much less and even not always positive. For 20012002 (model 2b), beech showed a negative response to increased light, whereas ash and sycamore showed a positive response to increased light; however, the effects were not nearly as strong as we had expected.

With gap establishment, gap centres received the highest light intensities, whereas soil moisture patterns (e.g., Figs. 4 and 5) showed a higher variability than light patterns, and moist areas were not only found in the gap centres but also in surrounding forest. As such, advance regeneration had the opportunity to positively respond to increased soil moisture at many places in the forest, so responses in plots with little regeneration and high soil moisture in the centre of the experimental gaps were masked.

Sycamore maple regeneration had reached a mean maximum height in 2000 of $59 \mathrm{~cm}$ and $1.6 \mathrm{~m}$ in 2002. Beech (27 cm in 2000; $1.2 \mathrm{~m}$ in 2002) and ash (23 cm in 2000; $1.3 \mathrm{~m}$ in 2002) were slightly shorter. The mean height in- 
crease for all seedlings from 2000 to 2002 is due to the change in sampling design (only seedlings $>50 \mathrm{~cm}$ ). This means that the mean height is not as high as it appears from the examples above. Likewise, it should be noted that the decreasing mean height (Fig. 7) for beech 1998 to 1999 and ash 1997 to 1999 was probably caused by new seedlings colonizing formerly empty plots and (or) by deer browse (see below).

In summary, we reject hypothesis $\mathrm{H} 1$ because we found little evidence for a positive relationship between regeneration height and density and the increased resource availability (light, soil moisture, and their interaction). Hypothesis H2 was also rejected: Although light and soil moisture availability was higher in the centre and just north of the gap centre, regeneration was not taller or denser at these positions. Instead, advance regeneration appeared to be a key factor in Als Nørreskov, which confirms hypothesis $\mathrm{H} 3$ that the presence of advance regeneration plays a crucial role in determining success of regeneration in gaps.

\section{The effect of fencing}

Ungulates may play an important role by influencing structure and dynamics of regeneration in deciduous forests. Their impact on forest vegetation has been extensively discussed especially in desire for sustainable management of both forest regeneration and wildlife (Reimoser and Gossow 1996; Cote et al. 2004; Moser et al. 2006). Problems are typically discussed for species that are rather susceptible to browsing: in this study, ash and, to some extent, sycamore maple. It was expected that these two species would increase significantly in height growth within fenced gaps.

In this study, we found few positive and significant effects of fencing on regeneration density or on height. This is in contrast to other European studies, which report sycamore maple to be one of the most affected species (Ammer 1996; Harmer 1999). However, Gill (1992) describes how different relative deer browse susceptibility is for various tree species at different sites. In Danish forestry practice, sycamore maple is usually not ranked as a species that is highly susceptible to browse. Finally, in accordance with Harmer (1999), no specific observations on higher mortality due to browsing were recorded. Thus, our impression is that deer populations in Als Nørreskov are within an acceptable range for regeneration success. Furthermore, it is likely that habitat structure of Als Nørreskov does not stimulate overbrowsing as also reported from other regeneration studies (Reimoser and Gossow 1996; Holladay et al. 2006). In summary, we reject hypotheses $\mathrm{H} 4$ and $\mathrm{H} 5$ because fences had no significant effects on regeneration density or growth within the timeframe of this study.

With regard to fencing, our impression was that the fences proved to be too large to completely keep all deer out. There were signs of roe deer activity inside one of three fences and after a windthrow in December 1999, where a tree had fallen down and damaged the fence, a roe deer was even observed inside this fence. Therefore, we suggest for future studies to make smaller and thus more efficient fences, which allow the animals to see the end of the enclosure, thereby limiting the urge to enter the enclosure. Additionally, such design will allow for more degrees of freedom in the statistical analyses of fence effects. Of course, the disadvantage is that such small fences (e.g., $100 \mathrm{~m}^{2}$ ) will not provide large areas of fenced regeneration to support longterm studies of deer-browse effects on, for example, forest structure and productivity.

\section{Implications for sustainable forest management}

The study provided several interesting conclusions for close-to-nature forest management. First of all, gap formation means an increase in resource availability (light and soil moisture), but the effect might be too short lived for regeneration to establish securely if gaps are small. Further, this means that successful establishment of regeneration and potential development into canopy trees depends on gap size or alternatively on a series of gap cuttings to expand the original gap or other kinds of canopy openings (Emborg 2007). Also, if light-demanding species are desired, gaps should be of substantial size and have the ability to stay relatively open for several years. Thus, future studies would benefit from a research design with a wider range of gap sizes than investigated here, with special emphasis on future gap expansion to facilitate regeneration and growth of more light-demanding tree species. Moreover, similar to the recommendation that forest managers need to be more patient with their expectations for the forest to respond to, for example, canopy opening, forest researchers probably also need to install long-term studies. Such studies may need to run for decades to retrieve and document the full effects of various treatments. This applies particularly to close-to-nature silviculture studies.

Another interesting outcome of the study is that advance regeneration is relatively secure, whereas seedlings established after gap formation are ephemeral. However, some of the new seedlings may very well become future advance regeneration waiting for future disturbance. Seedling growth is very slow below 5\% light (Madsen 1995b; Emborg 1998; Collet et al. 2001); thus, the formation of canopy gaps may serve to release seedlings that germinated and survived under low light levels. Other studies have shown that advance regeneration of beech can respond very rapidly to canopy opening and that very few seedlings regress or die following gap formation (Collet and Chenost 2006). This means that gaps should be cut where it is economically feasible (e.g., mature trees have reached a target diameter); however, if there is a choice between a site with and a site without advance regeneration, the forester may considerably shorten the next rotation period by harvesting where advance regeneration is already present. Otherwise, the forester may have to wait for several years or perhaps even decades before adequate densities of regeneration are present, especially for species with infrequent mast years. Alternatively, a more traditional Danish silvicultural approach that involves soil preparation with the beech seed fall may enhance seedling establishment, e.g., a light preparation during the later part of the seed fall. A third point, relating to the spatial distribution of regeneration within and around a gap, is that the prediction of where regeneration establishes appears to be a complicated interaction among stand structure, soil and microclimatic interactions, and past silvicultural treatments (e.g., thinnings) where chance also plays an important role (Hahn et al. 2007). Therefore, although detailed information on resource distribution is seldom available for the forester, a coarser approach may be useful. In this study, we divided the gap and surroundings 
into 11 broad positions as an attempt to avoid the dichotomy between "gaps" and "nongaps" and to reduce complexity and make the findings of the detailed experiment manageable. In practice it means that a division of the gap into a northern, central, edge and closed canopy section is detailed enough for predictions of e.g., regeneration height (Holladay et al. 2006). Finally, fencing, which is an expensive solution, seems almost unnecessary in systems like Als Nørreskov, where regeneration is otherwise unproblematic and browsing only plays a secondary role for regeneration survival and height growth. Thus, the forester should carefully, for example by installing very small $(10 \mathrm{~m} \times$ $10 \mathrm{~m})$ monitoring fences, evaluate the cost of fencing and maintenance against the loss of regeneration material and potential. Only if regeneration success falls below a defined threshold should actions be taken.

Sound management of regeneration in deciduous forests is essential to their long-term sustainability and productivity (Wagner and Lundqvist 2005). Close-to-nature forest management appears to be an important and flexible toolbox, in which gap regeneration is a highly useful tool to secure the sustainable development of these forests (Hahn et al. 2005). This tool mimics the openings of various sizes that follow moderate disturbance events, i.e., storms. Research in Als Nørreskov, which has been managed by close-to-nature principles for decades, showed that substantial regeneration in gaps does not establish immediately and, in some cases, not even over a 5 year period. Moreover, the quantified predictor variables were not adequate in describing abundance and height of gap regeneration. Two important findings were that advance regeneration, which was already present at the time of gap formation, played an important role and that sites with advance regeneration are those with regeneration success in the years following gap formation.

Over the 5 years following gap formation, gaps closed at a rather fast pace, primarily because of a vigorous canopy. This means that there is a limited effect of the increased resource availability (light and soil moisture). This is especially important for tree species with infrequent mast years, which depend on a larger regeneration window in both time and space, particularly in cases where regeneration conditions may vary from year to year (i.e., spring or summer droughts). Therefore, gaps created by felling of only three canopy trees are probably too small, even for shade-tolerant tree species for regeneration to reach canopy height. However, perhaps these smaller gaps are large enough to support establishment of future advance regenerations that will respond to future disturbances.

\section{Acknowledgements}

Many thanks to Professor J. Bo Larsen, who in the initial project phases was a driving force and a source of inspiration for this research project. Thanks also to Gråsten State Forest District for permitting research in Als Nørreskov and providing help with gap cutting and fencing. The project was supported financially by European Union projects Renfors and NatMan, and a research grant from KVL. We thank Maren Madsen, Arne Hahn, Jacob Kahl, Sara Lindholt, Sebastian Sørensen, Lars Birck, and Kristian Søgaard for help with data collection.

\section{References}

Ammer, C. 1996. Impact of ungulates on structure and dynamics of natural regeneration of mixed mountain forests in the Bavarian Alps. For. Ecol. Manage. 88: 43-53. doi:10.1016/S03781127(96)03808-X.

Andersen, S.S. 2000. Råvildtets indflydelse på østdanske bøgeforyngelser: et pilotstudie af mulige værktøjer til objektiv håndtering af råvildtet $\mathrm{i}$ det moderne skovbrug. M.Sc. thesis, Royal Veterinary and Agricultural University, Copenhagen, Denmark.

Angers, V.A., Messier, C., Beaudet, M., and Leduc, A. 2005. Comparing composition and structure in old-growth and harvested (selection and diameter-limit cuts) northern hardwood stands in Quebec. For. Ecol. Manage. 217: 275-293. doi:10.1016/j.foreco. 2005.06.008.

Aussenac, G. 2000. Interactions between forest stands and microclimate: ecophysiological aspects and consequences for silviculture. Ann. For. Sci. 57: 287-301. doi:10.1051/forest:2000119.

Bartsch, N. 2000. Element release in beech (Fagus sylvatica L.) forest gaps. Water Air Soil Pollut. 122: 3-16. doi:10.1023/ A: 1005265505479.

Bauhus, J., and Bartsch, N. 1996. Fine root growth in beech (Fagus sylvatica) forest gaps. Can. J. For. Res. 26: 2153-2159. doi:10. $1139 / \times 26-244$.

Christensen, M., and Emborg, J. 1996. Biodiversity in natural versus managed forest in Denmark. For. Ecol. Manage. 85: 47-51. doi:10.1016/S0378-1127(96)03749-8.

Collet, C., and Chenost, C. 2006. Using competition and light estimates to predict diameter and height growth of naturally regenerated seedlings growing under changing canopy conditions. Forestry, 79: 489-502. doi:10.1093/forestry/cpl033.

Collet, C., Lanter, O., and Pardos, M. 2001. Effects of canopy opening on height and diameter growth in naturally regenerated beech seedlings. Ann. For. Sci. 58: 127-134. doi:10.1051/ forest:2001112.

Collins, B.S., and Pickett, S.T.A. 1988. Response of herb layer cover to experimental canopy gaps. Am. Midl. Nat. 119: 282290. doi: $10.2307 / 2425811$.

Cote, S.D., Rooney, T.P., Tremblay, J.P., Dussault, C., and Waller, D.M. 2004. Ecological impacts of deer overabundance. Annu. Rev. Ecol. Evol. Syst. 35: 113-147. doi:10.1146/annurev. ecolsys.35.021103.105725.

Dalsgaard, L. 2007. Above- and below-ground gaps — the effects of a small canopy opening on throughfall, soil moisture and tree transpiration in Suserup Skov, Denmark. Ecol. Bull. 52: 81-102.

Degen, T., Devillez, F., and Jacquemart, A.L. 2005. Gaps promote plant diversity in beech forests (Luzulo-Fagetum), North Vosges, France. Ann. For. Sci. 62: 429-440. doi:10.1051/ forest:2005039.

Drössler, J., and von Lüpke, B. 2005. Canopy gaps in two virgin beech forest reserves in Slovakia. J. For. Sci. 51: 446-457.

Emborg, J. 1998. Understorey light conditions and regeneration with respect to the structural dynamics of a near-natural temperate deciduous forest in Denmark. For. Ecol. Manage. 106: 8395. doi:10.1016/S0378-1127(97)00299-5.

Emborg, J. 2007. Suppression and release during canopy recruitment in Fagus sylvatica and Fraxinus excelsior, a dendroecological study of natural growth patterns and competition. Ecol. Bull. 52: 53-67.

Emborg, J., and Heilmann-Clausen, J. 2007. The structure of Suserup Skov, 2002. Ecol. Bull. 52: 19-32.

Emborg, J., and Larsen, J.B. 1999. How to develop plantations into forests - in order to achieve stability and functional stability? A north European perspective. In Proceedings of the Interna- 
tional Experts Meeting on the Role of Planted Forests in Sustainable Forest Management, 6-9 April 1999, Santiago, Chile. Edited by S. Barros and M.I. Campodónico. Corporación Nacional Forestal (CONAF), Ministerio de Agricultura, Santiago, Chile. pp. 133-147.

Frich, P., Rosenørn, S., Madsen, H., and Jensen, J.J. 1997. Observed precipitation in Denmark, 1961-1990. Ministry of Transport, Danish Meteorological Institute, Copenhagen, Denmark. Tech. Rep. 97-8.

Galhidy, L., Mihok, B., Hagyo, A., Rajkai, K., and Standovar, T. 2006. Effects of gap size and associated changes in light and soil moisture on the understorey vegetation of a Hungarian beech forest. Plant Ecol. 183: 133-145. doi:10.1007/s11258005-9012-4.

Gill, R.M.A. 1992. A review of damage by mammals in north temperate forests: 1. Deer. Forestry, 65: 145-169. doi:10.1093/ forestry/65.2.145.

Hahn, K., and Thomsen, R.P. 2007. Ground flora in Suserup Skov: characterized by forest continuity and natural gap dynamics or edge-effect and introduced species? Ecol. Bull. 52: 167-181.

Hahn, K., Emborg, J., Larsen, J.B., and Madsen, P. 2005. Forest rehabilitation in Denmark using nature-based forestry. In Restoration of boreal and temperate forests. Edited by J. Stanturf and P. Madsen. CRC Press, Boca Raton, Fla. Integrative Stud. Water Manage. Land Dev. 3. pp. 299-317.

Hahn, K., Madsen, P., and Lindholt, S. 2007. Gap regeneration in four natural gaps in Suserup Skov - a mixed deciduous forest reserve in Denmark. Ecol. Bull. 52: 133-145.

Harmer, R. 1999. Survival and new shoot production by artificially browsed seedlings of ash, beech and sycamore grown under different levels of shade. For. Ecol. Manage. 116: 39-50. doi:10.1016/S0378-1127(98)00459-9.

Holladay, C.-A., Kwit, C., and Collins, B. 2006. Woody regeneration in and around aging southern bottomland hardwood forest gaps: effects of herbivory and gap size. For. Ecol. Manage. 223: 218-225. doi:10.1016/j.foreco.2005.11.004.

Kriebitzsch, W.U., von Oheimb, G., Ellenberg, H., Engellschall, B., and Heuveldop, J. 2000. Entwicklung der Gehölzvegetation auf gezäunten und ungezäunten Vergleichsfläche in Laubwäldern auf Jungmoränenböden in Ostholstein. Allg. Forst Jagdztg. 171: $1-10$.

Laursen, E.V., Thomsen, R.S., and Cappelen, J. 1999. Observed air temperature, humidity, pressure, cloud cover and weather in Denmark — with climatological standard normals, 1961-1990. Ministry of Transport, Danish Meteorological Institute, Copenhagen, Denmark. Tech. Rep. 99-5.

Madsen, P. 1994. Growth and survival of Fagus sylvatica seedlings in relation to light intensity and soil water content. Scand. J. For. Res. 9: 316-322.

Madsen, P. 1995a. Effects of seedbed type on wintering of beech nuts (Fagus sylvatica) and deer impact on sprouting seedlings in natural regeneration. For. Ecol. Manage. 73: 37-43. doi:10. 1016/0378-1127(94)03503-O.

Madsen, P. 1995b. Effects of soil-water content, fertilisation, light, weed competition and seedbed type on natural regeneration of beech (Fagus sylvatica). For. Ecol. Manage. 72: 251-264. doi:10.1016/0378-1127(95)97453-Y.

Madsen, P., and Fodgaard, S. 1989. Sønderborg skovdistrikt samtale med fhv. skovrider Paul Holbek, skovfoged Leo Vindahl Olsen, konst. Skovrider Peter Ilsøe. Skoven, 21: 157-159.

Madsen, P., and Larsen, J.B. 1997. Natural regeneration of beech (Fagus sylvatica L.) with respect to canopy density, soil moisture and soil carbon content. For. Ecol. Manage. 97: 95-105. doi:10.1016/S0378-1127(97)00091-1.
Madsen, P., Olsen, L.V., Skovsgaard, J.P., and Vesterdal, L. 1999. Naturnær skovdrift i Als Nørreskov. Skoven, 4: 178-180.

McClure, J.W., Lee, T.D., and Leak, W.B. 2000. Gap capture in northern hardwoods: patterns of establishment and height growth in four species. For. Ecol. Manage. 127: 181-189. doi:10.1016/ S0378-1127(99)00129-2.

Moser, B., Schutz, M., and Hindenlang, K.E. 2006. Importance of alternative food resources for browsing by roe deer on deciduous trees: the role of food availability and species quality. For. Ecol. Manage. 226: 248-255. doi:10.1016/j.foreco.2006.01.045.

Mountford, E.P., Savill, P.S., and Bebber, D.P. 2006. Patterns of regeneration and ground vegetation associated with canopy gaps in a managed beechwood in southern England. Forestry, 79: 389-408. doi:10.1093/forestry/cpl024.

Muth, C.C., and Bazzaz, F.A. 2002. Tree canopy displacement at forest gap edges. Can. J. For. Res. 32: 247-254. doi:10.1139/ x01-196.

Reimoser, F., and Gossow, H. 1996. Impact of ungulates on forest vegetation and its dependence on the silvicultural system. For. Ecol. Manage. 88: 107-119. doi:10.1016/S0378-1127(96)038169.

Ritter, E., and Vesterdal, L. 2006. Gap formation in Danish beech (Fagus sylvatica) forests of low management intensity: soil moisture and nitrate in soil solution. Eur. J. For. Res. 125: 139150.

Ritter, E., Dalsgaard, L., and Einhorn, K.S. 2005a. Light, temperature and soil moisture regimes following gap formation in a semi-natural beech-dominated forest in Denmark. For. Ecol. Manage. 206: 15-33. doi:10.1016/j.foreco.2004.08.011.

Ritter, E., Starr, M., and Vesterdal, L. 2005b. Losses of nitrate from gaps of different sizes in a managed beech (Fagus sylvatica) forest. Can. J. For. Res. 35: 308-319. doi:10.1139/x04-185.

Royal Danish Academy of Science and Letters. 1783. Map of Als and Als Nørreskov. Reprinted in Henriksen, H.A. 1996. Bøgeforyngelser i skove på Als. In Bøgeforyngelser i Østjylland. Edited by J.P. Skovsgaard and M. Morsing. Forskningscentret for Skov \& Landskab, Copenhagen, Denmark. Res. Ser. 13. p. 172.

Runkle, J.R. 1982. Patterns of disturbance in some old-growth mesic forests of North America. Ecology, 63: 1533-1546. doi:10.2307/1938878.

Schnitzler, A., and Borlea, F. 1998. Lessons from natural forests as a key for sustainable management and improvement of naturalness in managed broadleaved stands. For. Ecol. Manage. 109: 293-303. doi:10.1016/S0378-1127(98)00263-1.

Thomsen, A. 1994. AUTOTDR for making automated TDR measurements of soil water content. User's guide, version 01 edition, January 1994. Ministry of Agriculture, Danish Institute of Plant and Soil Science, Copenhagen, Denmark. SP Rep. 38.

Topp, G.C., Davis, J.L., and Annan, A.P. 1980. Electromagnetic determination of soil water content: measurements in coaxial transmission lines. Water Resour. Res. 16: 574-582. doi:10. 1029/WR016i003p00574.

Van Hees, A.F.M., Kuiters, A.T., and Slim, P.A. 1996. Growth and development of silver birch, pedunculate oak and beech as affected by deer browsing. For. Ecol. Manage. 88: 55-63. doi:10.1016/S0378-1127(96)03809-1.

Wagner, S., and Lundqvist, L. 2005. Regeneration techniques and the seedling environment from a European perspective. In Restoration of boreal and temperate forests. Edited by J. Stanturf and P. Madsen. CRC Press, Boca Raton, Fla. Integrative Stud. Water Manage. Land Dev. 3. pp. 153-171..

Webster, C.R., and Lorimer, C.G. 2005. Minimum opening sizes for canopy recruitment of mid-tolerant tree species: a retrospective approach. Ecol. Appl. 15: 1245-1262. doi:10.1890/04-0763. 
Welles, J.M., and Norman, J.M. 1991. Instrument for indirect measurement of canopy architecture. Agron. J. 83: 818-825.

Zeibig, A., Diaci, J., and Wagner, S. 2005. Gap disturbance pat- terns of a Fagus sylvatica virgin forest remnant in the mountain vegetation belt of Slovenia. For. Snow Landsc. Res. 79: 69-80. 